This effort at legal reform has won applause from environmental, health and industry groups alike. If passed, the law would be a welcome step in the right direction. Although chemical companies are understandably concerned about the extra costs such testing would entail, the new framework should make navigating the regulatory waters considerably more straightforward.

But scientific reform is needed as well. For decades, regulatory bodies have relied on guideline studies conducted under national and internationally agreed standards known as Good Laboratory Practice (GLP). This governs how the studies are planned, performed, monitored, recorded, reported and archived. These standards are invaluable, providing a guarantee of reliability and cross-comparability for studies on chemical safety. But the glacial pace of consensus building and validation required to update guidelines can leave gaping holes that allow the approval of chemicals of questionable safety.

A case in point is bisphenol A (BPA), a major component of polycarbonate plastics and resins widely used in consumer products, including food-can linings and baby bottles (see page 1122). Research in laboratories around the world has now produced many studies showing cognitive, developmental and reproductive effects associated with exposure to the chemical in lab animals. But because these effects seem to be triggered through BPA's hormone-mimicking qualities, and its long-term, epigenetic influence on gene expression, they can be considerably more subtle than the ones that guideline studies were designed to look for - those arising from more clearly toxic substances such as asbestos or thalidomide. Moreover, detecting BPA's effects generally requires cutting-edge biological techniques whose results, in the eyes of regulatory bodies, carry just a fraction of the weight of those produced by a GLP study.

This situation has to change. The scientists who develop these techniques need to put a high priority on validating and standardizing them in ways that make the results usable by regulators. And regulators need to find faster ways to get the new techniques incorporated into guideline studies. If they don't, keeping pace with the increasing speed at which chemicals are being developed and introduced will be impossible. Regulators are already overwhelmed by a backlog of consumer chemicals on which there are inadequate safety data. Yet now they are also having to grapple with nanomaterials and other novel compounds that need sophisticated science to evaluate, and sophisticated laws to regulate properly.

The new US legislation, although it may take some time to be enacted, could and should be shaped to encourage such changes. Regulators should not be expected to chase down every result produced by new and unproven methods. But they should be able to take into account new methods as rapidly as they can be validated.

\title{
Time for libel-law reform
}

\section{Simon Singh's recent libel result is a victory for science, but the real fight lies ahead.}

ustice prevailed last week when the British Chiropractic Association abandoned its libel action against the science writer Simon Singh - but it prevailed despite, rather than because of, English libel law.

This law is unique in the burden of proof it places on those accused of libel, and in allowing such accusations to be made against almost anyone whose words can be read in England. The result is a ridiculously tilted playing field that constrains free speech and open debate around the world - scientific debate included.

Singh's case is the most high-profile example, but there have been many others. British doctor Peter Wilmshurst is being sued in England after commenting on a clinical trial of a heart device in which he was involved. Danish radiologist Henrik Thomsen was sued after he made comments about a drug used in his field. Francisco Lacerda, of Stockholm University, has seen his work on the validity of lie detectors withdrawn from publication after threats of libel action. Science writer Ben Goldacre and The Guardian newspaper fought a long and costly battle with a promoter of vitamin treatments for AIDS.

Regardless of outcome - the Thomsen suit was settled earlier this year, for example - the use of English libel law to stifle debate should concern all researchers. For every case that comes to court, say campaigners for reform, there are many more in which scientists who lack the resources to fight just quietly back down, or worse, censor themselves even before publishing.
Against this dark background there is at last some light.

Not only has the 1 April ruling in Singh's favour from England's Court of Appeal forced the British Chiropractic Association to withdraw its libel action, but the court's judgment itself may offer wider protection to scientists and writers (see go.nature.com/EQFfg3). In particular, the judgment points approvingly to a 1994 US ruling also cited by Singh's legal team: "Scientific controversies must be settled by the methods of science rather than by the methods of litigation."

Concerns about scientific freedom are also found in a recent report on libel from the UK parliamentary Culture, Media and Sport Committee: "we believe that the fears of the medical and science community are well-founded, particularly in the internet age and with the growth of 'libel tourism."

Meanwhile, Singh's brave refusal to back down in the face of a potentially ruinous suit - unusual in being targeted at him personally, rather than at the newspaper that published his article - has given birth to a grass-roots campaign for fundamental reform of the libel law. Nature has backed this campaign (see Nature 459, 751; 2009), as have many scientists who recognize that they are just one publication away from being in Singh's position.

Better still, the politicians seem to be listening. With elections coming up in May, all three of the main UK parties have included promises of libel reform in their manifestos.

As heartening as these developments are, however, fulfilment of these promises is still a long way off. Reformers will need to keep up the pressure on whoever wins the British election next month. For speech to be truly free in England, the law must be rewritten to defend not just science, but all debates carried out honestly and in the public interest. 